\title{
ANALISIS CEMARAN MIKROBA PADA LEMPUK DURIAN SEBAGAI OLEH-OLEH KHAS PEKANBARU
}

\author{
Wahyu Margi Sidoretno ${ }^{1)}$ Muhammad Azhari Herli ${ }^{2)}$ \\ 1) Dosen, Analis Farmasi dan Makanan, FKIK, Universitas Abdurrab \\ J1. Riau Ujung No.73 Pekanbaru \\ email : wahyu.margi@univrab.ac.id \\ 2) Dosen, Analis Farmasi dan Makanan, FKIK, Universitas Abdurrab \\ J1. Riau Ujung No.73 Pekanbaru \\ email : azhari.herli@univrab.ac.id
}

\begin{abstract}
Tourism sector is an important thing in economy growth of an area. The safety of food products from tourism areas have to be increased. A bad quality food product (does not meet the qualification, safety, and contamination of pathogen microorganism) can cause some poisoning cases that is one of society health problems. Lempuk durian, made from durian and sugar, is a food product from Pekanbaru which is demanded. Beside of the sweet taste, the product has a good and delicious taste. This research aimed to increase the food safety of lempuk durian, so societies can be avoided from food poisoning because of pathogenic microorganisms. The result was compared with lempuk durian safety standard by SNI- 01- 4313- 1996. The microorganism contamination was determined using Total Disk Number method, and Coliform and Coliform fecal was measured with Most Probable Number method. The results obtained for ALT (total plate number) of samples A through E still meet the requirements required by SNI 7388 of 2009 on the maximum limit of microbial contamination in food that is 104 colonies / $\mathrm{g}$ and for MPN sample $\mathrm{C}$ that does not meet.
\end{abstract}

Keywords: Lempuk durian, Total Plate Number, Most Probable Number, Coliform-Colifecal

\section{ABSTRAK}

Sektor pariwisata merupakan tonggak penting dalam pertumbuhan ekonomi suatu daerah. Keamanan pangan terutama oleh-oleh juga harus semakin ditingkatkan. Produk pangan yang tidak memenuhi persyaratan mutu, keamanan dan cemaran bakteri patogen dapat mengakibatkan terjadinya kasus keracunan yang merupakan salah satu masalah kesehatan masyarakat. Oleh-oleh Pekanbaru yang diminati salah satunya adalah lempuk durian, yaitu pangan yang dibuat berbahan dasar durian dan gula. Selain manis, lempuk durian juga bercita rasa durian yang nikmat. Tujuan penelitian ini adalah meningkatkan keamanan pangan terhadap lempuk durian sehingga masyarakat dapat terhindar dari mikroba patogen yang dapat menyebabkan keracunan makanan. Hal ini diesuaikan dengan standar lempuk durian yaitu, SNI 7388 tahun 2009. Metode yang digunakan dalam penelitian ini adalah mengukur cemaran mikroba lepuk durian yang beredar dengan menetapkan Angka Lempeng Total (ALT), Pengujian Coliform dan Colifecal dengan metoda MPN (Most Probable Number). Hasil yang didapat untuk ALT (angka lempeng total) sampel A hingga E masih memenuhi persyaratan yang dipersyaratkan oleh SNI 7388 tahun 2009 tentang batas maksimum cemaran mikroba dalam pangan yaitu $10^{4}$ koloni/g dan untuk MPN sampel C yang tidak memenuhi.

Kata Kunci : Lempuk durian, Angka Lempeng Total, Most Probable Number, Coliform-Colifecal 


\section{Pendahuluan}

Pangan merupakan segala sesuatu yang berasal dari sumber hayati dan air, baik yang diolah maupun yang tidak diolah, yang diperuntukkan sebagai makanan atau minuman bagi konsumsi manusia, termasuk bahan tambahan pangan, bahan baku pangan dan bahan lain yang digunakan dalam proses penyiapan, pengolahan, dan atau pembuatan makanan atau minuman. Pangan merupakan kebutuhan terpenting manusia dibandingkan dengan yang lainnya, untuk memenuhi kebutuhan zat gizi dan juga sebagai sumber energi. Namun pangan juga dapat menjadi sarana pengganggu kesehatan manusia karena adanya kontaminasi oleh cemaran fisik, kimia maupun mikroba [1].

Hampir semua pangan, kecuali pangan steril dapat menjadi tempat hidup dan berkembang biak satu atau lebih jenis mikroorganisme. Beberapa jenis mikroorganisme dapat digunakan untuk memproduksi pangan fermentasi, tetapi beberapa jenis mikroorganisme dapat menyebabkan kerusakan pangan dan menimbulkan permasalahan kesehatan. Mikroorganisme merugikan merupakan miroorganisme yang kehadirannya dalam pangan dapat mengubah sifat organoleptik pangan yang tidak dikehendaki, menurunkan berat atau volume, menurunkan nilai gizi, mengubah bentuk dan susunan komponen pangan, serta dapat menghasilkan toksin. Mikroorganisme menguntungkan merupakan mikroorganisme yang kehadirannya dalam pangan dapat berperan pada proses produksi pangan, peningkatan nilai gizi pangan, menghasilkan bau dan cita rasa, serta berperan dalam perubahan warna pangan yang diinginkan [2].

Mikroorganisme tumbuh dan berkembang biak ketika berada dilingkungan yang cocok. Pangan merupakan media yang cocok untuk pertumbuhan berbagai jenis mikroorganisme, karena mengandung beragai nutrisi yang diperlukan untuk pertumbuhannya. Secara umum mikroorganisme yang terdapat dalam pangan terdiri atas kapang, khamir, bakteri, dan virus. Beberapa diantaranya adalah patogen, seperti Salmonella sp, Staphylococcus aureus, Escherichia coli, kapang, serta khamir [3]. Pencemaran mikroorganisme dalam pangan disebabkan adanya kontaminasi langsung atau tidak langsung dengan sumber pencemar mikroba. Penyakit yang disebabkan oleh pangan yang terkontaminasi bakteri antaralain; tipes, kolera, disentri, TBC, poliomilitis, dan lain sebagainya yang penularannya sangat mudah dari pangan. Akhir-akhir ini terjadi peningkatan gangguan saluran pencernaan akibat keracunan bahan pangan yang disebabkan oleh mikroorganisme patogen. Sebagai akibat dari meningkatnya perjalanan dan perdagangan terutama sektor pariwisata, sehingga faktor keamanan pangan sangat diperhatikan [4].

Keamanan pangan adalah tanggung jawab seluruh lapisan masyarakat selain BPOM sebagai pengawas peredaran makanan. Keamanan pangan penting dalam menjamin pangan yang aman dan layak dikonsumsi. Keamanan pangan adalah hak konsumen untuk mendapatkan perlindungan, hal ini diatur pada pasal 4 undang-undang No. 8 tahun 1999 tentang perlindungan konsumen. Pada tahun 2016, BPOM mencanangkan Bulan Keamanan Pangan Nasional, dengan tema "Pangan Aman Investasi Masa Depan". Tujuannya adalah meningkatkan budaya keamanan pangan di kalangan masyarakat, sehingga setiap individu diharapkan dapat secara mandiri memastikan bahwa pangan yang dikonsumsi selalu aman [1].

Pangan memiliki syarat yang ditetapkan oleh BPOM, bahwa makanan harus terjamin keamanannya. Keamanan pangan dapat di lakukan analisis secara organoleptis, fisika, kimia, kandungan logam dan pemeriksaan secara mikrobiologi. Keamanan pangan dapat di kaitkan dengan umur simpan atau dinyatakan dengan daluarsa. Salahsatu parameter umur simpan adalah mikroorganisme yang dapat menurunkan mutu atau kerusakan pangan [5].

Pengujian mikrobiologi pada makanan secara umum dapat dilakukan dengan parameter penetapan Angka Lempeng Total (ALT), angka paling mungkin (APM) Coliform dan Colifecal, pengujian Escherichia coli dan pada beberapa bakteri patogen lainnya [6], [7]. Pangan olahan yang paling dicari pada saat berkunjung ke kota Pekanbaru adalah lempok durian. Lempok durian adalah makanan semi basah yang dibuat dari daging buah durian (Durio zibethinus) matang yang dihancurkan, dimasak dengan penambahan gula, dengan atau tanpa penambahan bahan lain dan bahan makanan yang diizinkan.

Lempok durian biasanya dikemas dalam kemasan plastik, kertas atau dikemas dengan kulit nipah. Hal ini dilakukan untuk memperpanjang umur simpan dan menghindarkan dari cemaran mikroba kontaminan. Pengolahan yang sesuai dengan standart mutu pembuatan akan meningkatkan masa simpan dari makanan yang diolah. Tetapi cemaran hasil produksi masih dapat ditemukan pada makanan jadi yang diolah melalui Industri 
rumah Tangga (IRT). Untuk menjaga agar lempok durian memiliki keamanan pangan sesuai dengan yang disyaratkan oleh pemerintah, maka dilakukan penelitian terhadap parameter cemaran mikrobiologi.

Penelitian ini diharapkan dapat meningkatkan derajat kesehatan masyarakat terhadap keamanan pangan dan peningkatan status gizi masyarakat dengan menganalisis cemaran mikroba yang ada pada lepuk durian yang beredar di Pekanbaru dengan menetapkan Angka Lempeng Total (ALT), Pengujian Coliform dan Colifecal dengan metoda MPN (Most Probable Number).

\section{Tinjauan Pustaka}

\subsection{Lempok Durian}

Lempok adalah dodol dengan bahan utama dari buah durian yang merupakan makanan olahan tradisional andalan masyarakat Sumatera dan Kalimantan. Pembuatan lempok ini dilakukan secara turun temurun oleh masyarakat dengan teknologi sederhana. Siapa yang tak kenal dengan lempuk durian. Makanan khas Riau dari Kabupaten Bengkalis ini bahkan sudah melalang buana hingga ke manca negara Lempuk durian Bengkalis hampir tak mengenal musim. Hal ini sangat beralasan. sebab di Bengkalis, durian hampir ada sepanjang tahun. "Orang-orang banyak bertanya, mengapa lempuk durian di Bengkalis tak pernah hilang. Saya lantas menjawab, di Bengkalis musim durian tak pernah putus. Makanya lempuk selalu dapat diproduksi Bahan utama yang digunakan dalam dodol ini sangat digemari oleh banyak orang. Namun sayang harga salah satu makanan khas daerah ini relative cukup mahal. makanan ini sangat empuk dan wangi aroma durian sangat khas. memberikan ciri tersendiri makanan tersebut [8].

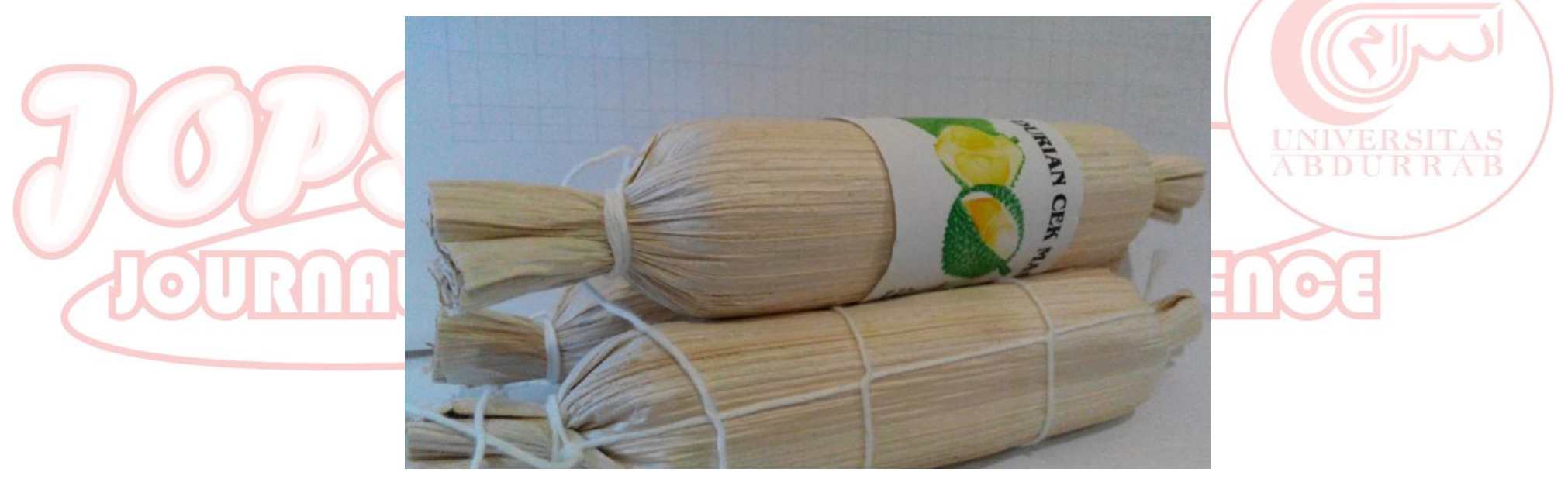

Gambar 1. Lempuk durian (www.google.co.id)

\subsection{Mikrobiologi}

Mikrobiologi adalah suatu kajian tentang mikroorganisme. Mikroorganisme itu sangat kecil, biasanya bersel tunggal, secara individual tidak dapat dilihat dengan mata telanjang. Mikroorganisme hanya dapat dilihat dengan bantuan mikroskop. Mereka tersebar luas di alam dan dijumpai pula pada pangan. Beberapa diantaranya, jika terdapat jumlah yang cukup banyak dapat menyebabkan keracunan makanan. Mikroorganisme merupakan penyebab utama merosotnya mutu pangan, misalnya kerusakan pangan. Namun demikian tidak semua mikroorganisme berperanan penting dalam semua bentuk kehidupan, karena mereka dapat memecah bahan organik kompleks dan mengembalikan unsur hara ke dalam tanah. Mikroorganisme juga dipergunakan oleh manusia untuk memproduksi beberapa jenis makanan, misalnya roti dan yogurt [9]. 


\subsection{Mikrobiologi Pangan}

Bahan makanan merupakan medium pertumbuhan yang baik bagi berbagai macam mikroba. Mikroba dapat membusukkan protein, memfermentasikan karbohidrat dan menjadikan lemak atau minyak berbau tengik. Keberadaan mikroba pada makanan ada yang tidak berbahaya bagi manusia, beberapa mikroba mengakibatkan kerusakan pangan, menimbulkan penyakit dan menghasilkan racun (Waluyo, 2004). Dalam upaya pencegahan kerusakan pangan, pertumbuhan mikroorganisme harus dicegah. Ini dapat dicapai dengan menghilangkan satu atau lebih kondisi yang diperlukan untuk pertumbuhan mikroorganisme. Salah satu metode pengawetan pangan yaitu dengan menggunakan pengawet, bahan ini tidak membunuh semua mikroorganisme, tetapi menghambat pertumbuhannya dan menunda kerusakan pangan [9].

\subsection{Mikroorganisme}

Mikroorganisme tersebar luas di alam lingkungan, dan sebagai akibatnya produk pangan jarang sekali yang steril dan umumnya tercemar oleh berbagai jenis mikroorganisme. Bahan pangan selain merupakan sumber gizi bagi manusia,juga sebagai sumber makanan bagi perkembangan mikroorganisme [10].

\subsubsection{Bakteri}

Bakteri Mungkin kelompok mikroorganisme yang paling penting dan beraneka ragam, yang berhubungan dengan makanan dan manusia adalah bakteri. Adanya bakteri dalam bahan pangan dapat mengakibatkan pembusukan yang tidak diinginkan atau menimbulkan penyakit yang ditularkan melalui makanan atau dapat melangsungkan fermentasi yang menguntungkan [10]. Perkembangbiakan bakteri dalam makanan ditentukan oleh keadaan lingkungan serta temperatur yang cocok selain ketersediaan zat gizi sebagai sumber makanan. Faktor yang menyokong perkembangbiakan organisme tersebut adalah temperatur, waktu, kelembapan, oksigen, $\mathrm{pH}$ dan cahaya [11].

Sumber Bakteri terdapat secara luas di lingkungan alam yang berhubungan dengan hewan, tumbuhtumbuhan, udara, air dan tanah [10]. Mereka dijumpai di udara, air dan tanah, dalam usus binatang, pada lapisan yang lembab pada mulut, hidung atau tenggorokan, pada permukaan tubuh atau tumbuhan [9].

Penyakit menular yang berbahaya yang disebabkan oleh bakteri yaitu demam tipus, kolera, disentri, TBC dan polio dengan mudah disebarkan salah satunya melalui bahan pangan [10].

\subsubsection{Khamir}

Khamir adalah mikroorganisme bersel tunggal dengan ukuran antara 5 dan 20 mikron. Biasanya berukuran 5 sampai 10 kali lebih besar dari bakteri [10]. Khamir adalah fungi bersel tunggal sederhana; kebanyakan bersifat saprofitik dan biasanya tumbuh pada pangan asal tanaman. Sel khamir dapat berbentuk lonjong, bentuk batang atau bulat. Berukuran lebih besar dari bakteri dan dengan mikroskop perbesaran kuat, intinya dapat dilihat dengan jelas [9].

Sumber Khamir terutama merupakan organisme yang bersifat saprofitik terdapat pada daun-daun, bunga-bunga dan eksudat dari tanaman. Serangga bertindak sebagai perantara memindahkan khamir dari satu tanaman ke tanaman lainnya. Khamir dapat diisolasi dari tanah, tetapi cenderung untuk tidak berkembang subur, populasinya dipenuhi oleh khamir yang terdapat pada buah-buahan atau daun-daun yang membusuk. Lingkungan yang bergula dan $\mathrm{pH}$ rendah seperti buah-buahan dan sirup merupakan tempat yang baik bagi pertumbuhan khamir. Penyakit yang Ditimbulkan Khamir tidak berperan dalam penyakit yang ditularkan melalui pangan [10]. 


\subsubsection{Kapang}

Kapang adalah fungi multiseluler yang mempunyai filamen dan pertumbuhannya pada makanan mudah dilihat karena penampakannya yang berserabut seperti kapas [12]. Sumber Kapang berlawanan dengan bakteri dan khamir, seringkali dapat dilihat dengan mata. Sifat pertumbuhan yang khas adalah berbentuk kapas dan biasanya terlihat pada kertas-kertas koran yang basah, kulit-kulit yang sudah usang, dinding basah, buahbuahan yang membusuk dan bahan pangan lain seperti keju dan selai. Pertumbuhannya dapat berwarna hitam, putih atau berbagai macam warna [10].

Penyakit yang Ditimbulkan Beberapa kapang dapat menyebabkan karsinogenik (menyebabkan kanker) yang berbahaya bagi manusia dan hewan [13]. Beberapa kapang dapat langsung bersifat patogenik dan menyebabkan penyakit tanaman dan manusia. Beberapa kapang merupakan penyebab berbagai infeksi pernafasan dan kulit pada manusia [10].

\subsubsection{Coliform dan Colifecal}

Coliform dan Colifecal merupakan suatu kelompok mikroorganisme yang digunakan sebagai indikator pencemaran terhadap air. Adanya Coliform dan Colifecal di dalam air menunjukkan kemungkinan adanya mikroorganisme yang bersifat enteropatogenik (bakteri penyebab diare) atau toksigenik yang berbahaya bagi kesehatan. Prinsip penentuan angka Coliform dan Colifecal ditandai dengan terbentuknya gas pada tabung durham setelah diinkubasi dengan media yang sesuai pada suhu $37^{\circ} \mathrm{C}$ dan pada suhu $44^{\circ} \mathrm{C}$ [12].

\section{Metode Penelitian}

Penelitian ini dilaksanakan dilaboratorium mikrobiologi Program Studi D III Analis Farmasi dan Makanan (ANAFARMA), FKIK, Universitas Abdurrab mulai bulan Oktober hingga November 2017.

\section{A. Sampel}

Sampel dalam penelitian ini adalah lempuk durian yang beredar dengan kemasan daun nipah, setelah dilakukan survei di peroleh 5 (lima) sampel dengan merek berbeda

B. Metode Penelitian

Metode penelitian ini menggunakan Angka Lempeng Total (ALT) dan Most Probable Number (MPN)

Coliform dan Colifecal.

\subsection{Angka Lempeng Total}

\section{Alat}

Alat yang digunakan dalam penelitian ini adalah erlenmeyer, gelas ukur, beaker glass, cawan petri, tabung reaksi, tabung durham, pipet tetes, pipet ukur, kawat ose, timbangan analitik, spatula, bunsen, autoclave, oven, dan inkubator.

\section{Bahan}

Bahan yang digunakan dalam penelitian ini adalah aquadest, alkohol $70 \%$, sampel (lempuk durian), media baffered peptone water (BPW), media plate count agar (PCA), dan larutan letheen broth.

\section{Prosedur Kerja Pengambilan Sampel}

Sampel diambil di beberapa pedagang makanan khas pekanbaru lempuk durian kemudian di simpan dalam suhu ruangan atau kamar. 


\section{Pengolahan Sampel}

Sampel dikocok homogen dan dipipet sebanyak $25 \mathrm{~mL}$ ke dalam labu steril yang telah berisi $225 \mathrm{~mL}$ larutan pengencer baffered peptone water (BPW) dan dikocok sampai homogen sehingga didapatkan pengenceran 10-1. Selanjutnya dilakukan pengenceran secara serial sehingga didapatkan pengenceran 10-2 dan seterusnya sampai 10-5.

\section{Sterilisasi Alat}

\section{Pemanasan dengan Udara Panas (Oven)}

Cara ini dipakai untuk membuat steril alat-alat dari gelas seperti tabung reaksi, petri-dish, botol dan alat-alat dan katun. Dengan cara ini pemanasan dilakukan sampai suhu $170^{\circ} \mathrm{C}$ (seratus derajat Celsius) selama 1 (satu) jam atau $140^{\circ} \mathrm{C}$ (seratus empat puluh derajat Celsius) selama 2 (dua) jam. Bila ada bahan dari katun, suhu jangan lebih dari $180^{\circ} \mathrm{C}$ (seratus delapan puluh Celsius) karena akan terbakar. Juga pada pendinginannya, bila suhu belum mencapai $100^{\circ} \mathrm{C}$ (seratus derajat Celsius); oven jangan dulu dibuka sebab alat-alat dari gelas akan pecah karena pendinginan yang mendadak.

\section{Pemanasan Uap Air yang Bertekanan (Autoclave)}

Alatnya disebut Autoclave. Cara ini paling baik karena suhu yang dicapainya tinggi dan air untuk koagulasi protein banyak. Dengan alat ini, besarnya tekanan uap air dapat diatur. Makin besar tekanan uap airnya, makin tinggi pula suhu yang dicapainya. Lamanya pemanasan bergantung pada tekanan uap yang dipergunakan, serta besar dan macamnya benda yang akan disterilkan. Pada tekanan uap 2 (dua) atmosfer di mana suhu yang dicapai $120^{\circ} \mathrm{C}$ (seratus dua puluh derajat Celsius), lama pemanasannya cukup selama 10-20 menit. Dengan cara ini, baik bentuk vegetatif maupun spora akan mati, sehingga mencapai steril sempurna.

\section{Sterilisasi Secara Kimia}

Antiseptik kimia biasanya dipergunakan dan dibiarkan menguap seperti halnya alkohol, umumnya alkohol 70-90\% adalah yang termudah namun merupakan antiseptik yang sangat efisien dan efektif.

\section{Desinfeksi Tempat Kerja}

Dilakukan desinfeksi tempat kerja menggunakan alkohol $70 \%$ pada tempat kerja. Meja dibersihkan dari debu, lalu disemprotkan dengan alkohol $70 \%$.

\section{Antiseptik Tangan}

Tangan dicuci dengan mengunakan sabun sampai bersih, kemudian disemprot menggunakan alkohol $70 \%$. Gunakan glove dan masker.

\section{Pembuatan Media (Plate Count Agar) PCA}

PCA ditimbang hingga diperoleh 7,05 gram dan dicampurkan dengan aquadest steril, kemudian atur pH netral 7,0 dan dipanaskan hingga larutan jernih. Langkah selanjutnya adalah PCA disterilkan menggunakan autoclave selama 15 menit pada suhu $121^{\circ} \mathrm{C}$.

\section{Prosedur Pemeriksaan ALT}

1. Sampel yang akan diuji terlebih dahulu dihomogenkan dalam larutan pepton pengencer (baffered peptone water, BPW) sehingga didapat pengenceran $10^{-1}$.

2. Dari hasil pengenceran tersebut, dipipet sebanyak $1 \mathrm{ml}$ ke dalam tabung pertama yang berisi 9 $\mathrm{ml}$ larutan pengencer PDF sehingga diperoleh pengenceran $10^{-2}$.

3. Campuran dikocok homogen. Pengenceran dilakukan demikian seterusnya sehingga diperoleh pengenceran bertingkat $10^{-3}, 10^{-4}, 10^{-5}$, dan seterusnya.

4. Larutan letheen broth digunakan karena dapat menginaktifkan pengawet dalam sampel dapat menghambat pertumbuhan bakteri. 
5. Dari setiap hasil pengenceran, dipipet $1 \mathrm{ml}$ ke dalam cawan petri dan dibuat duplo. Selanjutnya, ke dalam setiap cawan petri, dituang sebanyak 15-20 ml media plate count agar (PCA) yang dicairkan pada suhu $45^{\circ} \pm 1^{\circ} \mathrm{C}$. Cawan petri segera digoyangkan perlahn supaya sampel tercampur rata dengan media perbenihan.

6. Setelah media membeku, cawan petri diinkubasi pada suhu $35-37^{\circ} \mathrm{C}$ selama $24-48$ jam dengan posisi terbalik.

7. Pertumbuhan koloni pada setiap cawan yang mengandung 30-300 koloni dicatat. Pada setiap pemeriksaan, selalu disertakan media kontrol uji (blanko). Angka lempeng total untuk 1 gram atau $1 \mathrm{ml}$ sampel dihitung dengan mengalikan jumlah rata-rata koloni pada cawan dengan faktor pengenceran.

\section{Analisis Data}

\section{Teknik Pengumpulan Data}

Data diperoleh dari hasil pemeriksaan jumlah koloni Angka Lempeng Total (ALT) yang dilakukan di Laboratorium Mikrobiologi Universitas Abdurrab.

\section{Pengolahan Data}

Dari hasil pemeriksaan Angka Lempeng Total (ALT) Laboratorium Mikrobiologi terhadap pencemaran mikroba pada lempuk durian data yang diperoleh dari hasil penelitian disajikan dalam bentuk tabel dan dijelaskan secara diskriptif.

\subsection{Most Probable Number (MPN)}

Pengerjaan Sampel

Sampel dibuat dengan pengenceran $10^{-1}$ yaitu ditimbang 10 gram sampel diencerkan dengan $90 \mathrm{ml}$ BPW (Buffer Peptone Water) di dalam Erlenmeyer. Dipipet sebanyak $1 \mathrm{ml}$ pengenceran $10^{-1}$ masukkan ke dalam tabung yang telah beisi $9 \mathrm{ml}$ BPW (Buffer Peptone Water) sehingga diperoleh suspensi dengan pengenceran $10^{-2}$, kemudian dibuat pengenceran $10^{-3}$.

\section{Cara Pembuatan Media Laktosa Broth (LB) Dan Brillian Green Laktosa Broth(BGLB)}

\section{a. Media Laktosa Broth (Single)}

Larutan media laktosa broth (LB) 1,3 gram dalam $100 \mathrm{ml}$ aqudest (pemakaian media LB 13 gram / liter) kemudian dipanaskan sampai homogeny setelah itu larutan tersebut dimasukkan ke dalam masing-masing tabung reaksi sebanyak $10 \mathrm{ml}$ yang telah berisi tabung durham yang dalam keadaan terbalik, kemudian di bolak balik agar tidak terdpat gelembung udara didalam tabung durham lalu disterilkan dalam autoklaf pada suhu $121^{\circ} \mathrm{C}$ selama 15 menit.

\section{b. Media Laktosa Broth (Triple)}

Laktosa LB 3,9 gram dalam $100 \mathrm{ml}$ aquadest (pemakain media LB 13 gram / liter) kemudian dipanaskan sampai homogen, kemudian larutan dimasukkan ke dalam maing-masing tabung reaksi sebanyak $10 \mathrm{ml}$ yang telah berisi tabung durham yang keadaan terbalik, kemudian dibolak balik agar tidak terdapat udara didalam tabung durham lalu disterilkan dalam autoklof pada suhu $121^{\circ} \mathrm{C}$ selama 15 menit.

\section{c. Media Brilliant Green Laktosa Broth}

Larutan media BrilliantGreen Laktosa Broth (BGLB) 20 gram dalam $500 \mathrm{ml}$ aquadest (pemakaian media BGLB 40 gram / liter) kemudian dipanaskan sampai homogen. Masukkan sebanyak $10 \mathrm{ml}$ ke dalam masing-masing tabung reaksi yang berisi tabung yang dalam keadaan terbalik kemudian dibolak balikagar tidak terdapat udara didalam tabung durham lalu disterilkan dengan autoklaf pada suhu $121^{\circ} \mathrm{C}$ selama 15 menit. 


\section{Prosedur Pemeriksaan MPN}

\section{a. Uji Pendahuluan}

Dilakukan penanaman dengan ragam 5: 1: $1(5 \times 10,1 \times 1,1 \times 0,1 \mathrm{ml})$ sampel. Sampel diamsukkan sebanyak $10 \mathrm{ml}$ ke dalam 5 tabung reaksi yang telah berisi laktosa (LB triple), kemudian dimasukkan $1 \mathrm{ml}$ sampel kedalam tabung reaksi yang telah berisi Laktosa Broth (LB single) dan 0,1 $\mathrm{ml}$ sampel diamsukkan kedalam tabung reaksi yang telah berisi Laktosa Broth (LB single) yang telah berisi tabung durham sebelumnya. Kemudian dinkubasi dengan inkubator pasa suhu $37^{\circ} \mathrm{C}$ selama 24-48 jam. Positif, bila terdapat gelembung gas pada tabung durham. Dicatat tabung durham yang positif.

\section{b. Uji Penegasan}

Dipindahkan 1 ose kedalam tabung reaksi yang berisi $10 \mathrm{ml}$ media BGLB dari Laktosa Broth yang positif dengan dua seri penanaman pada suhu $37^{\circ} \mathrm{C}$ untuk Coliform dan pada suhu $44,5^{\circ} \mathrm{C}$ Colifrorm fecal selama 24 jam. Baca hasil pada media BGLB yang berbentuk gelembung. Hasil positif dihitung dengan melihat index MPN pada Tabel MPN.

\section{Hasil dan Pembahasan}

\subsection{Hasil}

\subsubsection{Angka Lempeng Total}

Tabel I. Hasil Sampel A (YANTI)

\begin{tabular}{|c|c|c|}
\hline \multirow{2}{*}{ Pengenceran } & \multicolumn{2}{|c|}{ Jumlah Koloni Bakteri } \\
\cline { 2 - 3 } & Petri 1 & Petri 2 \\
\hline $10^{-2}$ & 1 & 1 \\
\hline $10^{-3}$ & 8 & 1 \\
\hline $10^{-4}$ & 1 & 2 \\
\hline $10^{-5}$ & 2 & 4 \\
\hline
\end{tabular}

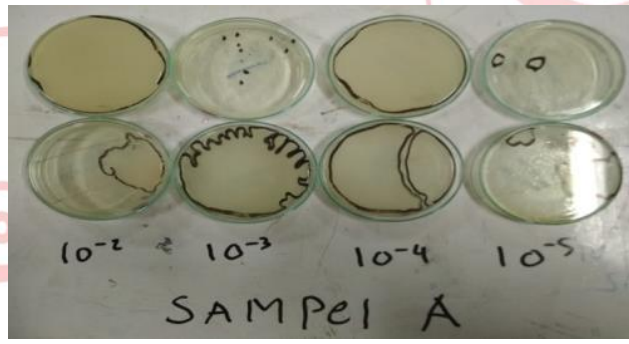

Tabel II. Hasil Sampel B (MEGA RASA)

\begin{tabular}{|c|c|c|}
\hline \multirow{2}{*}{ Pengenceran } & \multicolumn{2}{|c|}{ Jumlah Koloni Bakteri } \\
\cline { 2 - 3 } & Petri 1 & Petri 2 \\
\hline $10^{-2}$ & 12 & 2 \\
\hline $10^{-3}$ & 2 & 3 \\
\hline $10^{-4}$ & 6 & 1 \\
\hline $10^{-5}$ & 3 & 3 \\
\hline
\end{tabular}

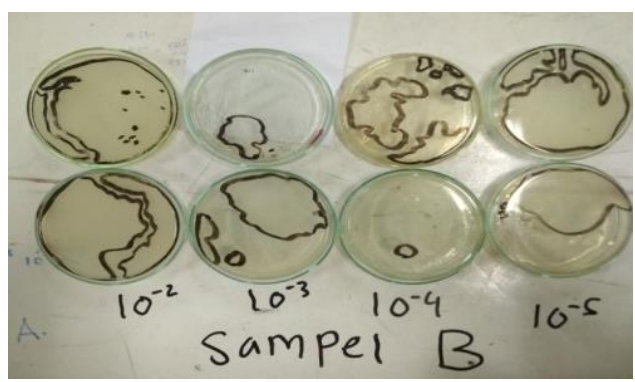


Tabel III. Hasil Sampel C (CITRA RASA)

\begin{tabular}{|c|c|c|}
\hline \multirow{2}{*}{ Pengenceran } & \multicolumn{2}{|c|}{ Jumlah Koloni Bakteri } \\
\cline { 2 - 3 } & Petri 1 & Petri 2 \\
\hline $10^{-2}$ & 7 & 6 \\
\hline $10^{-3}$ & 1 & 2 \\
\hline $10^{-4}$ & 4 & - \\
\hline $10^{-5}$ & 2 & - \\
\hline
\end{tabular}

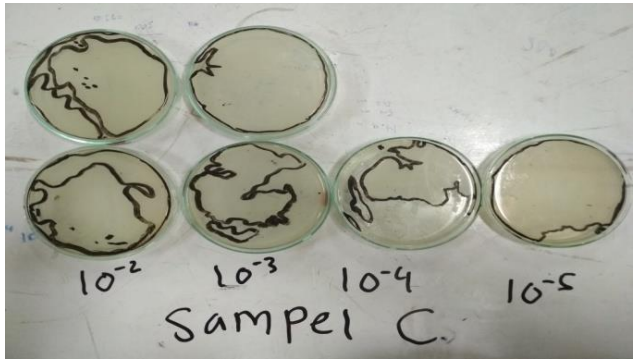

Tabel IV. Hasil Sampel D (CEK MAS AYU)

\begin{tabular}{|c|c|c|}
\hline \multirow{2}{*}{ Pengenceran } & \multicolumn{2}{|c|}{ Jumlah Koloni Bakteri } \\
\cline { 2 - 3 } & Petri 1 & Petri 2 \\
\hline $10^{-2}$ & 68 & 57 \\
\hline $10^{-3}$ & 69 & 18 \\
\hline $10^{-4}$ & 5 & 6 \\
\hline $10^{-5}$ & 26 & 23 \\
\hline
\end{tabular}

Tabel V. Hasil Sampel E (MEKAR SARI)

\begin{tabular}{|c|c|c|}
\hline \multirow{2}{*}{ Pengenceran } & \multicolumn{2}{|c|}{ Jumlah Koloni Bakteri } \\
\cline { 2 - 3 } & Petri 1 & Petri 2 \\
\hline $10^{-2}$ & 3 & 1 \\
\hline $10^{-3}$ & 5 & 1 \\
\hline $10^{-4}$ & 1 & 6 \\
\hline $10^{-5}$ & 1 & 6 \\
\hline
\end{tabular}

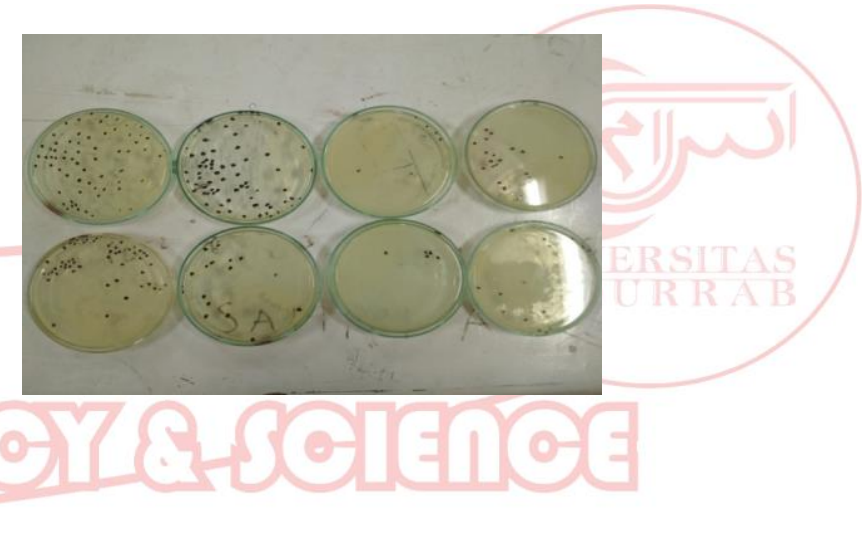




\subsubsection{Most Probable Number (MPN)}

Tabel VI. Hasil Pengujian Most Probable Number (MPN) tabung Ragam 5-1-1

\begin{tabular}{|c|c|c|c|}
\hline SAMPEL & UJI & \multicolumn{2}{|c|}{ UJI PENEGASAN } \\
\cline { 3 - 4 } & PENDAHULUAN & COLIFORM & COLIFECAL \\
\hline A & $3-0-1$ & $0-0-0$ & $2-0-0$ \\
\hline B & $4-0-1$ & $0-0-0$ & $0-0-0$ \\
\hline C & $5-1-1$ & $2-0-0$ & $2-1-1$ \\
\hline D & $2-0-0$ & $0-0-0$ & $0-0-0$ \\
\hline E & $0-0-0$ & $0-0-0$ & $0-0-0$ \\
\hline
\end{tabular}

\subsection{Pembahasan}

Pengujian ALT (angka lempeng total) dan MPN (most probable number) dalam Lempok durian merupakan dua pengujian yang harus dipenuhi oleh produsen karena merupakan persyaratan minimal lempok durian layak dikonsumsi oleh konsumen. Menurut SNI 7388 tahun 2009 tentang batas maksimum cemaran mikroba dalam pangan, Lempok durian harus memenuhi 6 persyaratan yaitu seperti pada tabel VII dibawah ini [14] :

\section{Tabel.VII. SNI 7388 tahun 2009 tentang batas maksimum cemaran mikroba dalam} pangan untuk Lempok

\begin{tabular}{|l|l|l|}
\hline Lempok dan analognya & $\mathrm{ALT}\left(30^{\circ} \mathrm{C}, 72 \mathrm{jam}\right)$ & $1 \times 10^{4} \mathrm{koloni} / \mathrm{g}$ \\
\cline { 2 - 3 } berbasis buah & $\mathrm{APM}$ Koliform & $20 / \mathrm{g}$ \\
\cline { 2 - 3 } & $\mathrm{APM}$ Escherichia coli & $<3 / \mathrm{g}$ \\
\cline { 2 - 3 } & Salmonella sp. & negatif $/ 25 \mathrm{~g}$ \\
\cline { 2 - 3 } & Staphylococcus aureus & $<1 \times 10^{1} \mathrm{koloni} / \mathrm{g}$ \\
\cline { 2 - 3 } & Kapang dan khamir & $1 \times 10^{2} \mathrm{koloni} / \mathrm{g}$ \\
\hline
\end{tabular}




\section{Kesimpulan}

Dari hasil diatas didapat untuk ALT (angka lempeng total) sampel A hingga E masih memenuhi persyaratan yang dipersyaratkan oleh SNI 7388 tahun 2009 tentang batas maksimum cemaran mikroba dalam pangan yaitu $10^{4} \mathrm{koloni} / \mathrm{g}$ dan untuk MPN sampel $\mathrm{C}$ yang tidak memenuhi.

\section{REFERENSI}

[1] R. BPOM and P. B. M. C. M. Dan, "Peraturan Kepala Badan Pengawas Obat Dan Makanan Republik Indonesia Nomor HK. 00.06. 1.52. 4011," Jkt. BPOM, 2009.

[2] T. Sopandi, "Wardah. 2014," Mikrobiol. Pangan Teori Dan Prakt.

[3] M. J. Pelczar, E. C. S. Chan, and R. S. Hadioetomo, Dasar-dasar mikrobiologi. Universitas Indonesia, 1988.

[4] W. P. Rahayu, C. C. Nurwitri, L. Nuraida, and R. T. Hariyadi, Mikrobiologi pangan. Bogor (ID): IPB Press, 2012.

[5] H. Herawati, "Penentuan umur simpan pada produk pangan," J. Litbang Pertan., vol. 27, no. 4, pp. 124-130, 2008.

[6] A. D. R. Dewi and W. H. Susanto, "Pembuatan Lempok Pisang (Kajian Jenis Pisang dan Konsentrasi Madu)," J. Pangan Dan Agroindustri, vol. 1, no. 1, pp. 101-114, 2013.

[7] N. Andarwulan and P. Hariyadi, "Perubahan mutu (fisik, kimia, mikrobiologi) produk pangan selama pengolahan dan penyimpanan produk pangan," Pelatih. Pendugaan Waktu Kedaluwarsa, 2004.

[8] W. Darwis and P. Pardiyono, "Mikoflora pada lempuk durian," GRADIEN, vol. 1, no. 1, pp. 30-32, 2014.

[9] P. M. Gaman, K. B. Sherrington, and M. Gardjito, Ilmu Pangan: Pengantar Ilmu Pangan, Nutrisi dan Mikrobiologi. Gadjah Mada University Press, 1994.

[10] R. K. Mulyowidarso, G. H. Fleet, and K. A. Buckle, "Association of bacteria with the fungal fermentation of soybean tempe," J. Appl. Bacteriol., vol. 68, no. 1, pp. 43-47, 1990.

[11] M. B. Arisman, Buku Ajar Ilmu Gizi: Keracunan Makanan. Penerbit Buku Kedokteran EGC, Jakarta, 2008.

[12] D. S. Fardiaz, Mikrobiologi pangan 1. PT Gramedia, 1992.

[13] D. A. Nurwantoro and A. Siregar, "Mikrobiologi Pangan Hewani-Nabati," Penerbit Kanisius Yogyak., 1997.

[14] S. N. Indonesia, "Batas maksimum cemaran mikroba dalam pangan," SNI, vol. 7388, p. 2009, 2009. 